\title{
THE ROLE OF ETHICS IN TECHNICAL EDUCATION
}

\author{
Dipali Yadav \\ Department of IT
}

MGMCET, Navi Mumbai, Maharashtra, India

\author{
Madhuri Patil \\ Department of IT \\ MGMCET, Navi Mumbai, Maharashtra, India
}

Abstract - This paper provides a narrative review of the role of ethics in education, the primary objectives of ethics in education for teachers, recommended teaching and learning strategies. The most vital objective of education ought to be to equip the scholars with moral values. Education ought to aim at creating human life higher not solely but through economic upliftment of the individual however, additionally through social, ethical and religious strengthening. Education isn't solely some way of earning however it additionally helps to develop human temperament with skills, values, morals and sweetening of various attributes of man.

Today most of the unsocial activities square measure being committed by well-educated new generation. The connection between teacher and student lack confidence towards one another. Students lack humanitarian attitude towards different persons, family, society and therefore the nation. Thus, there's greater urgency to think about ancient education system in India. Without imparting values and morals in education, human development is going to be incomplete. Qualities and ethics are inbuilt in individual and Education should help in the change of human character and acknowledgment of their inner purity, so the basic piece of training framework ought to underline the qualities and ethics with other development.

\section{Keywords-Ethics, Indian education system, Moral \& Values}

\section{INTRODUCTION}

We learn moral values from family and education. These are two important institutions, where we learn how to behave in a society. within the pre-independence era, only few people had access to formal education and it had been noted that educated persons would show civilized behavior, decency, courtesy and moral conduct, on the opposite hand, Uneducated persons would show uncivilized behavior and most of the crimes were committed by them. However, with a huge expansion of the education system, there's a marked decline within the characters, moral ethical values. Today most of the crimes are coming out by the students of schools and colleges and well-educated people.
In India, to increase ethical moral values it is essential to think philosophical, study, research and moral development in education system.

In ancient time of India, the education system was very prosperous, value-based. The teachers were concerned about total improvement of students which includes their intellectual (Physical, mental and spiritual ) level, understand their abilities, be aware of responsibilities, regards for elders, appreciation for cultural heritage, responsibility towards their fellow social group. In the present education system, we are not seen these qualities. Before discussion and finding solution to these issues there is a need to understand the concept of moral values, ethics \& Education.

\section{A. Concept of Moral Values, Ethics and Education-What is Morality?:}

In morality people have strong beliefs about what's right and wrong. Morals can vary from and culture to culture, person to person, as they result form of basic human emotions.

\section{B. What are Ethics?-}

Ethics in general is considered the study of right and wrong in human being. At a more fundamental level, it's the strategy by which we have a tendency to categorize our values and pursue them to determine what is ethically good for the individual and for the society.

\section{Why Ethics is so important?}

The simplest and best answer for this is to save humanity on planet. We humans are forgetting the morals and destroy everything for the sake of money. Education should not be business, the most important objective of education should be to equip the students with ethical values, of course we cannot say everything is wrong but there is no limit for this act.

\section{Education:}

Education is not simply imparting knowledge in a particular course or providing the students the job security or performing well in exams, but at the same time making students think logically that will help them to sustain in the changing environment. It also will help in opening the doors of their mind, cleansing the soul and realization of the self. Education should aim at making human life better not only through economic upliftment of individual but also through social, moral and spiritual strengthening. This will not only improve 
human life but also to realize the "higher truth" i.e. "Tamaso Ma Jyotirgamaya" from darkness to light. Thus education is not only a way of to earn money but it also helps to develop human personality with skills, values, morals and enhancement of different attributes of man. So education is a important means for the potentialities of a human being to emerge in a positive direction so that a man can live in society with full of dignity.

Education is a tool for total development of human, if any one aspect of human personality is ignored, it can result very adversely. Without imparting values and morals in education, human development will be incomplete. Values and morals are inbuilt in human being and Education should help in the improvement of human character and recognition of their inner purity, so the essential part of education system should emphasize the values and morals with other development.

\section{E. Moral Values in Education:}

The moral values in humans are lessening day by day, every generation is losing some extent of morality. Some of the core human values are shown in fig. 1

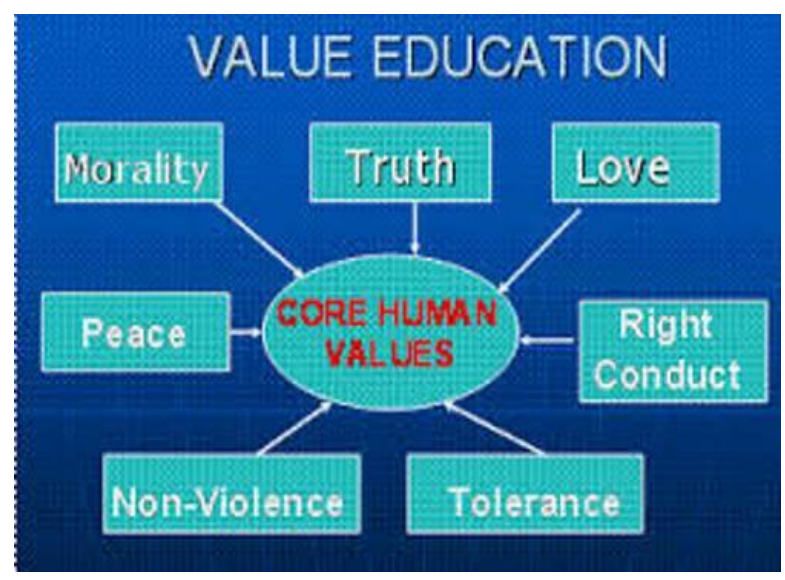

Fig.1 Core Human Values

\section{F. Present Education system:}

There are tremendous changes in society such as modernization, industrialization, urbanization, privatization, globalization as well as influence of western culture accompanied many problems in Indian society that cause declining ethical values in Indian education system. The rate of literacy has increased but it did not help in creating well cultured individual in the society and as a result it does not produce ideal citizens in the country. The students are becoming more career oriented. Their main objective has remained only to take degree, to earn money and to be careerist without inculcating ethical values in their life. Nowadays, problems are encountered in the Indian society which are never ending such as uncontrolled corruption, unlawful activities, inhuman behavior and immoral consumption which is resulting in decreasing human values.
This is thus affecting the structure of Indian society, nation and the world.

\section{G. Unethical behaviour of Students}

1.They are making proxy signature of their friends who are absent in the classroom.

2.The students are doing several unethical behavior. In examination, they carry cheats with them, and are caught under several unfair means.

3.They are doing forgery of signatures of their parents, teachers, head of departments and even of head of the Institutions.

4.When teachers are calling parents meet, the students are bringing fake person and pretend that they are their parents.

5.The students are bunking the classes and roaming in the campus. They lie at home that they are attending the classes and tell lies to the teachers that they could not attend the classes because they have issues at the home.

\section{H. Importance of Ethics in Society and Engineering Industry}

Engineers have an ethical responsibility for its safety and welfare because of the impact of their work on society. To have ethical responsibility, an engineer's requires understanding the importance of ethics, and its application in engineering endeavors. Ethics is first taught by parents and family members and is a important part in maturity. Within everyday life and career, ethics are deeply woven into the decision-making processes, making it a standard of life. These standards should be harvested and refined through higher education. In higher education, it is essential to highlight engineers' role in the safety of communities, making clear the role for applied ethics. An ethical issue is a situation that requires a person to choose between alternatives that must be evaluated as ethical (right) or unethical (wrong)[6]

\section{Inadequate Emphasis of Ethics in Education}

The lack of understanding of ethics in the engineering industry is due to weaknesses in engineering education. Three of the objectives in ethical education are to help students want to make ethical decisions, to have the ability to make these decisions, and most simply, to be aware of the relevant codes and guidelines guiding the appropriate ethical practice.

The teaching ethics to engineering students is difficult because the students' focus and loyalty towards their technical work takes up so much time. The time period of four years is not enough time to take in the vast amount of technical knowledge and skills as well as the societal, political, and ethical implications of their engineering projects. Engineering students enter the engineering industry without the essential education that provides the ethical understanding that the society requires. This isbecause of the lack of standard methods or focus on ethics education. This shows that there is a problem in engineering education, and it needs to be 
addressed to solve the engineering industry's failure of ethics understanding.

\section{J. Current Education Structures and Practices}

Due to the lack of current structures, problem in engineering education and practices is raised for instilling ethics understanding. Tools to emphasize importance of ethics include the professional engineering code of ethics and engineering codes of standards institution accreditation requirements, and attempts at the ethics education in engineering.

Engineering institutions did not require their students to take an ethics-related course. The institutions that do have a requirement for ethics-related courses often do not offer specialized courses in engineering ethics. Many departments simply include small ethics lectures in the curriculum. For this reason, many classes lack emphasis on ethics and lead to an undereducated student. The problem escalates when engineering faculty lack the commitment to implement ethics material into their courses. Engineering professors would rather focus on the technical aspects of engineering than ethics because that is their expertise. Students also lack the interest to learn ethics or realize its importance.

Students are not held responsible for understanding and applying the material, and this sends the message that these issues are not as important as the technical ones which are graded with more care. Engineering students, consider the ungraded assignments (non technical subjects) as superfluous and time consuming over the graded assignments(technical subjects), especially when time pressures are intense.

When designing a module to teach students how to better analyze ethical issues, the emphasis can be given to open their minds by forcing the students to argue against themselves.

This can be done simply by assigning a case study to students and asking for their opinion on the ethical issue. Then students analyze the situation and give their solutions to the ethical issue. After the analysis, the debate can be organized in class. the students received their next assignment using the same case study. This next assignment was to now analyze the case study, and provide an argument for the opposite solution to what they previously proposed. This forces the students to argue against their biases and look at the situation from a different, and more neutral, perspective. They must provide an argument and solution to the case study that opposes their original views, and they must back this argument with valid evidence.

This method for teaching with case studies is important because it provides the students with a platform to see situations from different perspectives and create multiple arguments so that all bases of an ethical issue are apparent.

The first step involves identifying the ethical issues in the case study, the stakeholders, and basic information for each issue. The next step is to identify and present possible solutions for each issue. Afterwards each possible solution should be analyzed for its the pros and cons along with how the stakeholders of the issue are affected. Arguments for each issue will be presented to show how it will solve the issue and the reasoning behind it. Each possible solutions of each issue should be compared to each other to determine which is most feasible, benefits the most, and is the most morally acceptable. The final step is picking the best solution based on this comparison. The reasoning behind the choice should be stated using answers from previous questions along with a counter argument to possible opposition. The goal of this method is to give students a systematic way to analyze a case study for the ethical issues and make decisions to solve them. For complex case studies, there might be many ethical issues to address and applying this analysis method for all of them is time consuming. The students should identify all of the issues for the case study for step 1 . The students will then be instructed to apply steps 2-6 for just one of those issues. This will allow the students to use the full process of the analysis method at least once, so they know how to use it in the future. After the analysis is complete, the students will discuss the issues they found, their chosen solutions, and their reasoning for these solutions in class. Discussion is an important aspect of teaching ethics skills, and participation is crucial.

\section{CONCLUSION}

In this paper, we conclude that students do not receive proper education in the study of ethics in engineering. They lack this ability to deal with ethics and to recognize that ethics is part of every engineering decision. This is in part due to a lack of emphasis on ethics education at the university level. Based on literature, an across the curriculum model was found to be a proper pathway to improving ethics education. Within the time constraints of this project, only part of an across the curriculum model was able to be tested. Case studies have been proven to be effective teaching resources for many different facets of engineering, including ethics education.

\section{REFERENCES}

[1] Dr.Yadav Urmila,January, 2016 "Ethical Moral values \& Indian Education System" Annual International Seminar Proceedings(1).

[2] John Fielder, "Issues in Ethics Making an Engineering Ethics Video: Engineering, Ethical Education, and Adult Learniing", Vi//anova University and Patricia A. Lawle; Widener University

[3] Sarah K.A. Pfatteicher,Summer 2002 "LEARNING FROM FAILURE:Terrorism and Ethics in Engineering Education “,IEEE Technology and Society Magazine

[4] Brinkman, Miami University2012 "The Next Step for Ethics Education Is Enforcing the Code",IEEE Computer Society.

[5] John P Sullins, "Case Study in Malware Research Ethics Education, IEEE Security and Privacy Workshops 
International Journal of Engineering Applied Sciences and Technology, 2019 Vol. 3, Issue 12, ISSN No. 2455-2143, Pages 67-70

Published Online April 2019 in IJEAST (http://www.ijeast.com)

[6] Meghan Cantwell, Peter Lam, Kevin Reyer, Richard Matthew Rafferty, "Improving Ethics Education in

Engineering", IEEE Communications Magazine 